\title{
5. Bildbruket i klosterkyrkan
}

\section{Bilderna i betraktarnas närhet}

Idén till den här undersökningen av Vadstena klosterkyrkas bildvärld hade sin upprinnelse $\mathrm{i}$ handskrifternas bilder, men har vidgats till att omfatta de bildbärande föremål och bilder som fanns innanför kyrkans väggar kring sekelskiftet 1500. Den har skiftat mellan mikro- och makroperspektiv på kyrkorummets bilder och deras funktion. Inledningsvis diskuterades förutsättningarna i kyrkorummets gestaltning och de olika bildmiljöer som formades i klosterkyrkan under loppet av 1400-talet. Därefter har de olika brukargruppernas bildsfärer diskuterats, understundom ända ned på stygnnivå.

Böckerna var en viktig del av den nära bildmiljön för klosterfolket. Några intressanta skillnader mellan de båda konventens bevarade handskrifter kan iakttas. Till att börja med finns det betydligt mer material som täcker hela 1400-talet från brödernas konvent, än från systrarnas. I nunnornas handskrifter är materialet från decennierna kring 1500 helt dominerande, liksom det liturgiska innehållet, men så är alltså inte fallet i brödernas samling. I brödernas samling finns en större kronologisk och innehållsmässig bredd. En konsekvens av den innehållsmässiga skillnaden är att medan systrarnas böcker huvudsakligen skrevs i formell skrift, gotisk textualis och hybrida, är brödernas egentillverkade bruksböcker skrivna i gotisk kursiv eller halvkursiv stil. Kursiv stil ledsagas generellt sett sällan av påkostade dekorer i medeltida handskrifter, och bokmåleri påträffas därför i mindre utsträckning i brödernas bevarade boksamling. Ytterligare en skillnad mellan konventens böcker är avsaknaden av guld i de inhemskt tillverkade handskrifterna från brödernas konvent. Det guld som förekommer i brödernas bibliotek återfinns enbart i de importerade handskrifterna och de tryckta böckerna, förutom möjligen den i kapitel 3 nämnda Summa aurea-miniatyren. (Bild 60.) I nunnornas handskrifter finns det däremot både guldoch silverinitialer från årtiondena kring 1500.

Nunnornas egen tidegärd, Cantus sororum, innehåller inga figurativa framställningar i det bevarade Vadstenamaterialet, och de handskrifterna är över lag sparsamt dekorerade. Detta är en skillnad jämfört med en del andra birgittinkloster 
där bokmåleri förekommer även i Cantus sororum-handskrifterna. Däremot har det funnits mer eller mindre omfattande bildprogram i de andra bönböckerna i Vadstenasystrarnas konvent. Trots handskrifternas omfattande bildförluster sedan medeltiden går det att identifiera många motiv med hjälp av de texter som bilderna illustrerat. Där möter framförallt många framställningar av jungfru Maria och andra helgon samt scener ur passionsberättelsen. Bland de under senmedeltiden populära andaktsmotiven märks Gregoriusmässan, Smärtomannen och olika varianter på framställningar av Kristi sår. Vissa bilder av jungfru Maria och flera av de nämnda populära motiven var förknippade med utfästelser om avlat, ibland knutna till en viss andaktsbild i klosterkyrkan, t.ex. jungfru Maria. De avlatsförknippade bilderna skulle betraktas i samband med vissa andaktsövningar, vilket är en viktig bruksaspekt. Bild och bön hängde ihop. Andaktsövningar med särskilda böner, kopplade till specifika bilder, utfördes av både klosterfolk och besökare och uppmuntrades genom avlatsbrev. Nunnornas flitiga visuella anspelningar på Ave Maria-bönen är en indikation på detta, men det gällde även de andra kyrkobesökarna. Bilder av det sårade hjärtat som framställning av Kristi sår ses också i kombination med passionsredskapen och anspelningar på jungfru Maria. Betoningen av den nära förbindelsen mellan Kristus och hans moder Maria är ett återkommande tema, vilket ligger helt i överensstämmelse med både den allmänna dåtida och den birgittinska fromheten.

Det verkar som om bröderna inte anlitade nunnorna för den bokliga dekorens utformning i någon direkt omfattning. Däremot samarbetade man med skrivandet $\mathrm{i}$ åtminstone åtta bevarade verk, och även med bokbinderiet. ${ }^{759} \mathrm{På} \mathrm{precis} \mathrm{samma}$ sätt som bland nunnorna verkar några av de skrivande bröderna ha haft en större fallenhet för den bokliga dekoren än andra, men det finns inget som tyder på att skrivuppgiften var skild från bokmåleriet i brödernas skriptorium heller. Den som kopierade en text ansvarade huvudsakligen för att förse sitt verk med den dekor som passade. Det förefaller som man följt samma praxis i båda skriptorierna under hela 1400-talet. De i kapitel 2 nämnda m-formade marginalrankorna framstår emellertid som ett överbryggande av uppdelningen mellan konventen. (Bild 23, 25, 27, 30.) Dessa marginaldekorer har varit populära på båda sidorna av konventsmurarna decennierna runt sekelskiftet 1500. Det innebär att bröderna kunde betrakta samma marianska mikrosymbolik i sina handskrifter som nunnorna.

Klosterbrödernas bildvärld präglades (kapitel 3) av de föremål som behövdes för liturgin, främst vid något av klostrets egna altaren: mässböcker, altarkärl och liturgiska textilier. Till att börja med var det de sexton mässaltarna, påbjudna av heliga Birgitta, men under årens lopp kom ytterligare en handfull altaren till inom klausuren. De som nämns i samband med silverreduktionen 1540 är sex ytterligare klosteraltaren. Det innebär att bröderna kan ha haft tjugotvå olika altaren att betjäna i kyrkan, men det är oklart om de tjänstgjorde vid de klosterförbundna altarna utanför klausuren eller om det sköttes av andra präster.

759 UUB C 74, C 420, C 450, C 451, KB A 22, RA Fr 30072, Fr 30246-30247. Isak Collijn tolkar bokbindarinstruktionerna i bibeln UUB Ink 33:38-39 att bokbindaren broder Nils Larsson bundet några av systrarnas bönböcker, se Lindblom et al. 1918 s 168. 
Bildvärlden som bröderna mötte när de slog upp handskrifterna de använde vid altaret var troligen begränsad. Missalet UUB C 420 har en enda bild, (bild 46) strategiskt placerad för att som brukligt vördas av prästen i samband med kanonbönen. Mer prakt och guldglans fanns i de många importerade teologiska handskrifterna i brödernas omfattande bibliotek, men den bildvärlden har inte gett några påtagliga bevarade avtryck annat än i enstaka fall, som den nämnda miniatyren på Summa aurea-fragmentet i Vadstena Landsarkiv. (Bild 60.) Vad Gustav Vasa och inbrottstjuvarna Mats och Staffan tog med sig ur boksamlingen 1543 respektive 1557 är tyvärr inte känt, men man kan gissa att det var sådant som ansågs mer värdefullt, sannolikt illuminerat med guld.

De flesta av de textilier som hörde till högaltaret och de tolv apostlaaltarna har försvunnit i samband med stölder, försäljningar och efter klosterstängningen 1595. De drygt tjugotalet bevarade liturgiska dräkterna eller delar därav ger trots detta en antydan om att man hade tillgång till både goda material och hög kompetens att tillverka det som klostret behövde. Samtidigt tog man troligen emot gåvor både i form av färdiga textilföremål och som material för att använda vid den egna tillverkningen av paramenta. En del av textilierna bär tydliga spår av att ha varit profana prakttextilier innan de förvandlades till exempelvis mässhakar och dalmatikor. Den röda sammeten i mässhaken från Björklinge kyrka ses även i ett flertal andra plagg och föremål från klostret. Det tyder på att man haft tillgång till en större väggtextil som räckt till flera mässhakar och tunikor/dalmatikor. En del av figurbroderierna är importerade och har monterats som ryggkors och bårder på mässhakar etc. av nunnorna. Bilderna som pryder de bevarade textilierna visar att de hör hemma i den allmänna samtida spiritualitetshistoriska kontexten.

Den av nunnorna broderade ornamentiken är mestadels utförd som applikationer och domineras av rosor, stjärnor, liljor, fleur-de-lys och påfågelsfjädrar. Hit hör också andra symboler som pelikan, hjortar och hjärtan. I dessa lokalt utförda broderier kommer sötvattenspärlor ofta till användning. Textilierna som nunnorna tillverkat är mättade av symboler för jungfru Maria, heliga Birgitta, Kristi kärleksgärning och anspelningar på den innerliga förbindelsen mellan Kristus och Maria. I de Vadstenatillverkade figurbroderierna möter betraktaren skildringar ur Annaoch Joakimlegenden, jungfru Marias liv, passionsberättelsen, Birgittas Himmelska uppenbarelser och olika helgon. Scenerna är gärna placerade i rundbågar och utförda i sammanhängande sviter i en för systrarna typisk teknik, yttäckande klyvsöm. (Bild 34, 37.) Ikonografiskt är det jungfru Maria som dominerar i det bevarade liturgiska textilmaterialet. Brödernas bildvärld fick därmed en mariansk prägel tack vare och i likhet med nunnornas. Textilierna är på sätt och vis en mer sammanlänkande föremålsgrupp än någon annan i klostret eftersom systrarna satte sin prägel på dem i tillverkningen, men de brukades av bröderna. Paramentan skapade i hög grad klosterfolkets gemensamma visuella referensramar.

För lekfolkets del var det i hög grad de många kapellens och altarnas bilder som tillsammans med alla votivgåvorna präglade besöket. På så vis var det ett konventionellt katolskt kyrkorum. Tydligast visuell betoning i deras del av kyrkorummet hade dock heliga Birgitta själv tillsammans med de birgittinska grundarna - dottern 
Katarina och magister Petrus Olofsson. Trots den stora mängden lekmannaaltaren och inbyggda kapell kunde kyrkorummets båda poler framträda för besökaren: omedelbart innanför dörren kunde man se Birgittaaltaret och eventuellt relikskrinet därovan, och när man riktade blicken mot väster fångades den av högkorets rika gestaltning med det upphöjda högaltaret och de många apostlaaltarna. Det är svårt att tolka källorna om hur det såg ut i högkoret, med de tolv flankerande apostlaaltarna i plogformation nedanför. Flera frågor kvarstår. Kunde lekfolket se den celebrerande prästen? Stod han vänd mot öster eller väster? Hade dessa altaren helgonbilder på både fram och baksida? När firades mässa vid de tolv apostlaaltarna? Information om ett tydligare betonat högaltare ges i berättelsen från Katarinafesten 1489, liksom att man då skapade en form av baldakin för det. Det framgår också att högaltaret fram tills dess hade två altartavlor, riktade åt väst respektive öst, så att både lekfolket och bröderna hade möjlighet att se dem från sina olika platser. ${ }^{760}$ Det är ett originellt arrangemang.

\section{Betraktarnas perspektiv i kyrkorummet}

Vadstena klosterkyrka skapades enligt heliga Birgittas instruktioner för att fylla ett liturgiskt behov för tre olika grupper samtidigt: nunnor, klosterbröder och lekfolk. Som vi sett var det tre brukargrupper som var fysiskt separerade, och när det gäller nunnorna så var de inte ens synliga för de övriga som rörde sig i kyrkan. Nunnorna kunde bara höras, inte ses. Deras sång skulle höras som änglasång från nunneläktaren uppe under valven. Den rigorösa klausuren var inte lika sträng när det gällde klosterbröderna som för nunnorna. Brödernas existensberättigande i klostret var att betjäna nunnorna andligen. De hade dessutom ett utåtriktat uppdrag gentemot lekfolket som kom till kyrkan. Bröderna kunde och skulle både höras och ses av besökarna. De skulle predika för dem. Dessa dubbla uppdrag berördes ovan i kapitel 3. Lekfolket var de som i princip kunde ses av alla, men de kunde inte se nunnorna. De rörde sig enbart i den gemensamma centrala delen av kyrkan, delvis under nunnornas läktare, och några få av dem undantagsvis på herrskapsläktaren på norra vägen. Besökarnas fysiska tillgång till klostrets egna altaren begränsades av det järngaller som löpte runtom hela kyrkorummets inre, men de hade möjlighet att se de många klosteraltarna genom gallret. Deras erfarenheter av klosterkyrkan präglades av de många privata kapellen och altarstiftelserna, grundade av rikets adel i överensstämmelse med de fromhetsinriktningar som var aktuella under 1400-talets lopp. De flesta altare som fanns där hörde till dem man kunde finna i de flesta större kyrkor och katedraler, även om de var ovanligt talrika just i klosterkyrkan.

För systrarnas del var bildvärlden i kyrkan i första hand avgränsad till deras upphöjda läktare. När de befann sig på läktaren hade de det upphöjda Mariaaltaret i öster, prytt med en stenskulptur av jungfru Maria och kanske även en altartavla. Stenskulpturen var troligen den som klostret fått från dotterkonventet i Gdansk

760 Fritz \& Elfving 2004 s 33. 
redan 1397. Mariaaltarets framsida pryddes sannolikt av ett rött liljedekorerat altarbrun med den blåklädda strålomgivna apokalyptiska madonnan i mitten. (Bild 39.) Mellan nunneläktaren och Mariakoret reste sig det stora Birgittaaltaret, vilket gjorde att systrarna från ovan kunde se något av även dess altarskåp, genom det galler som sannolikt avgränsade läktaren mot öster. Det är också tänkbart att heliga Birgittas silverskrin hade sin upphöjda plats i Mariakoret, så att systrarna kunde se det från sin läktare. Den föreslagna placeringen innebär att herrskapet kunde se skrinet från sin läktare i nordmuren och att lekfolket på golvet kunde passera under det, när de under sin vandring kring pilgrimsmålet också gick bakom altaret. På nunnornas eget andaktsaltare stod ständigt den påbjudna monstransen, vilken de verkar ha bevarat ända till klosterstängningen 1595. Förmodligen pryddes detta lite mindre altare av altarbrunet med bland annat passionsscener, helgon och textcitat ur Cantus sororum (SHM 23022:7). (Bild 34.) På den västra insidan av läktaren fanns femton målade scener ur passionsberättelsen, en birgittinsk passionssvit. ${ }^{761}$ Inför den nionde scenen, korsbärandet, stannade de upp och knäföll varje fredag under sin Botpsalmsprocession

Även om nunnornas placering uppe på läktaren är oomtvistlig, så har olika forskare presenterat olika tänkbara alternativ för nunneläktarens exakta placering och hur den hängde ihop med resten av byggnaden. Iwar Anderson redogjorde för flera olika varianter (se ovan kap. 1), men ingen av dem förefaller optimal. ${ }^{762}$ Inte heller Bertil Berthelsons äldre rekonstruktionsförslag löser problemen för hur den dagliga liturgin skulle praktiseras. ${ }^{763}$ Heliga Birgittas instruktioner angav bara vilken relativ höjd läktaren skulle ha, byggnadsmaterialet samt att den skulle vara "mitt i" kyrkan. Det finns aspekter på läktarens placering som tillsammans med de bevarade planerna i förstone skulle kunna tyda på att läktaren varit förankrad i Mariakoret, vilket ju också var placerat en våning upp från kyrkgolvet. Det skulle innebära att den travé som ligger längst mot öster, i kyrkans mittskepp, delades mellan Mariakoret och nunneläktaren, gemensamt uppburna av de båda slankare pelare som syns bredvid Birgittaaltaret på de äldre planerna. Det scenariot innebär en nunneläktare omfattande 1,5 travé i mittskeppet, vilket ger tillräckligt med utrymme för de sextio korstolarna, pulpet, andaktsaltare och passionstavlorna. För att de olika nivåerna på dörr- och fönsteröppningar ska fungera tillsammans leder det för det första till att Birgittaaltaret hamnar under nunneläktaren, dvs. utanför systrarnas synfält. För det andra innebär det att nunnorna hamnar högre upp än Mariaaltaret. Båda dessa nivåplaceringar förefaller osannolika i relation till nunneläktaren, och därmed även hela läktarens placering mot öster. En annan lösning måste sökas.

Tack vare den redan omtalade georadarundersökning som 2018 genomfördes i norra sidogången, mellan kyrkbänkarna och den stora orgeln samt i mittgången i kyrkan, påträffades pelarfundament som bidrar till att justera bilden av nunneläktarens

\footnotetext{
761 Den birgittinska passionssvitens särdrag nämndes ovan i kap. 2.

762 Anderson 1991 s 79 fig. 80.

763 Berthelson 1947 s 71-79.
} 
placering. ${ }^{764}$ Två pelarfundament påträffades i den andra travén från öst i mittskeppet och ytterligare två i den tredje travén. Det medför att minst fyra försvunna murade pelare sannolikt har stöttat upp läktaren, förutom att den torde ha varit infäst i fyra av de valvbärande pelarna. Två av de nyfunna pelarbaserna var placerade i öst-västlig riktning i mittskeppets tredje travé, och två i nord-sydlig riktning i dess andra travé. (Bild 14.) Genom de funna resterna av pelarnas placering kan nunneläktaren förskjutas något i sin öst-västliga utsträckning och troligen även ges en avsmalnande östlig avslutning, men ingen förbindelse med Mariakoret. Resultatet innebär att merparten av nunneläktaren bokstavligen verkligen hamnar mitt i kyrkans långhus, i dess mittersta travé, samt att den sträcker sig in i halva nästa travé i öst. Det ger utrymme för en ca $160 \mathrm{~m}^{2}$ stor läktare med plats för de sextio korsystrarna, läspulpet, andaktsaltare. ${ }^{765}$ För nunnornas del medför utformningen/placeringen fördelen att de kunde se både Birgittaaltaret och Mariaaltaret samtidigt, om än på olika nivåer. Dessutom är det, som föreslagits, även tänkbart att heliga Birgittas silverskrin stod i detta blickfång, i Mariakoret. Läktarplaceringen leder också till att nunnornas gångbro från den norra muren har anslutit till läktarens främre, dvs. östra del. Det innebär att när nunnorna tågade in hälsade de först det egna koraltaret och monstransen och sedan svängde de 90 grader mot väster och intog sina platser i korstolarna.

Från sina korstolar på läktaren kunde nunnorna alltså rikta blickarna mot öster, den viktigaste och uppståndelsens riktning, och samtidigt mot heliga Birgitta själv och jungfru Maria. Även över dem svävade från 1466 en bild av jungfru Maria. På närmare håll kunde de också se Kristus i form av hostian i monstransen på deras eget andaktsaltare. Andaktsaltaret pryddes av ett altarbrun med helgonfigurer och scener ut den birgittinska versionen av passionsberättelsen, inramad av en för systrarna bekant text ur Cantus sororum. Riktade de istället blickarna mot väster så kunde de se framställningar av Kristi lidande, i närmiljön framställd i de femton passionsscenerna på läktarbröstningens insida, samt höja blicken bort mot högaltaret och apostlaaltarna. I triumfbågen över högaltaret hängde det stora krucifixet. ${ }^{766}$ Det var således ett kristologiskt bildtema i väster och ett birgittinskt-marianskt i öster.

Vadstenabrödernas bildvärld avgränsades främst till deras tidebönskor, bakom högaltaret. (Bild 47.) Där var de i hög grad avskärmade av det på trappsteg placerade högaltaret och dess altarskåp. Det innebär att högaltaret samtidigt var deras andaktsaltare. Liksom hos nunnorna stod korstolarna i rader mittemot varandra på nord och sydsidan och för att se högaltaret vred bröderna huvudet åt öster. Här fanns också läspulpet och en stol till veckomannen/hebdomadarian. Ovanför högaltaret hängde alltså triumfkrucifixet och österut kunde de ana såväl nunneläktaren som kanske även vissa lekmannakapell, men högaltaret skymde nog den sikten i hög grad. Mariakoret kunde de knappast se från denna position p.g.a. den stora nunne-

\footnotetext{
764 Undersökningen genomfördes inom projektet Multisensoriska aspekter på Vadstena kloster i samarbete med LTH, Lund.

765 Leksystrarnas plats i kyrkan är inte utredd.

766 En placering som liknar den i Kloster Lüne, se https:/www.kloster-luene.de/klosteranlage/ geschichte/ [20200825].
} 
läktaren, men de firade regelbundet mässa vid Mariaaltaret. På sin väg till den heliga jungfruns altare passerade de först apostlaaltarnas rad och sedan gick de upp på ena sidoläktaren. Därifrån kunde de skåda ned på de många kapellen och altarna samt gravstenarna på kyrkgolvet. Den broder som valde den södra läktargången passerade S Mikaels altare, medan den norra läktaren gick förbi Johannes döparens altare och den i muren inbyggda herrskapsläktaren. När bröderna kommit längst bort i öster svängde de för att, via trappor, komma upp i Mariakoret på den östra väggens mitt. Mariaaltaret pryddes troligen av den gotiska stenmadonnan från Danzig. När prästbrodern firade mässan gjorde han det inför heliga Birgitta och systrarna, och vid elevationen höjde han den kalk som Birgittas son Birger donerat till just detta altare. Altarets front pryddes av ett färgrikt antependium, ett par broderade stukor samt troligen ett broderat rött altarbrun med den blåklädda apokalyptiska madonnan i mitten. (Bild 39.) Under mässfirandet var bröderna iförda de liturgiska textilier som systrarna tillverkat, sannolikt med broderade mariabilder på mässhakens rygg, krage och besättningar. En tänkbar mässhake är den som en gång prytts av det röda korset med nio mariamonogram och blå kantband med gyllene rosor och minuskel-m, och som tillhört Skara domkyrka. ${ }^{767}$ (Bild 26.) När den celebrerande prästbrodern och hans ministranter vände sig om mot väster kunde de inte se något av högkoret, men däremot kanske silverskrinet som avtecknade sig mot Birgittaaltarskåpets gyllne krön av gotiska ornament, och bort mot den närbelägna nunneläktaren och dess insynsskyddande läktarbröstning.

Vi lämnar de upphöjda läktarna och kliver ned till lekfolket på golvet. Den Vadstenapilgrim som klev in genom kyrkportarna i öst och sökte sig genom rummet, förbi kyrkans alla privata kapell och altaren och fram till högkoret i väster, mötte onekligen en imponerande syn där de tolv apostlaaltarnas rad ledde blicken upp till högaltaret. (Bild 49.) Högkoret och området kring järngallrets grind var ett område laddat med Kristi efterföljare: apostlarna och Birgittas närmaste efterföljare: dottern Katarina och magister Petrus. För besökaren som sedan vände sig om mot öster, svävade nunneläktaren som en ö mitt i rummet. Där under reste sig en mängd altare och kapell vid pelarna, utmed sidoläktarna och som fristående rum. Från denna position kunde man se Birgittaaltaret $\mathrm{i}$ öst, och kanske skönja något av Mariakoret ovanför. Marias och Birgittas pol var i östra änden av kyrkan, den främsta delen. I Birgittakapellet lyste det förmodligen fler ljus än vid något av de andra kapellen i kyrkan. Trots att nunneläktaren var stor och sannolikt täckte mer än en travé i mittskeppet, var det nog inte så mörkt därunder. Den var högt placerad och de höga ljusa fönstren i alla fyra väderstreck bidrog till ljusinflödet, tillsammans med de många brinnande ljusen som reflekterades i guld- och pärlbroderierna och Birgittakorets altartavla. För det mesta var det troligen en hel del folk i rörelse kring Birgittakoret. Den pilgrim som ställde sig mitt i Birgittakapellet kunde förmodligen se det upphöjda silverskrinets prakt och hur Mariakoret avtecknade sig mot östväggen, bakom Birgittaaltarskåpet. Att på pilgrimers vis ta sig runt Birgittaaltaret, som mirakel-

767 En av de vita mässhakarna i stängningsinventariet 1595 hade ett kors "sänkt med guld", dvs. guldläggsöm, vilket ev. skulle kunna svara mot detta kors. Se Silfverstolpe 1895 s 154. 
berättelsen om Kristina från Gärdslätt visar, innebar dessutom att passera under heliga Birgittas skrin och Mariakoret. Här var man så nära man kunde komma både jungfru Maria och heliga Birgitta, samtidigt. Det var ett område med hög dignitet i kyrkan. Rimligen fanns det en plats inom detta utrymme där man lämnade sina gåvor till jungfru Maria, under hennes altare i den östligaste mittravén. Här, nära jungfru Maria och heliga Birgitta, fick även några av klostrets lekbröder och leksystrar sin sista vila.

\section{Ett birgittinskt bildbruk}

När heliga Birgitta föreskrev att endast motiv ur Kristi passion och helgonens liv tilläts i kyrkan, medförde det egentligen inte en begränsning. I praktiken gav det ett generöst utrymme för föreställande bilder. Genomgången har visat att de olika bildteman som lekfolket mötte i klosterkyrkan var typiskt senmedeltida allmänkatolska. Flera av bilderna hörde till de mest populära, ofta avlatsförknippade, motiven, exempelvis Gregoriusmässan, Veronica, Smärtomannen och den apokalyptiska madonnan. Avlatsanknytningen innebar i sig att de också var förknippade med utförandet av specifika andliga övningar, främst böner. Ibland räckte det med att recitera Ave Maria eller Pater noster, men ibland krävdes mer aktiv läskunnighet för att utföra övningarna. Lekmannaaltarna visar på sina stiftares preferenser när det gäller helgonurval och andaktsteman och gav på det viset adeln ett stort inflytande över utformningen av lekfolkets kyrkorum. Hur stort klostrets eget inflytande var i lekfolkets del av kyrkan kan därför diskuteras, förutom när det gällde Birgittakapellet och sedermera även drottning Filippas S Annakapell. Skildringen från Katarinas skrinläggning 1489 visar dock på att klostret tog ett övergripande ansvar för gestaltningen, oavsett vilken sida av klausurgränsen det handlade om. Arrangemangen kring Katarinafesten visar också på en bildstrategisk medvetenhet genom upphängandet av t.ex. de specialtryckta Katarinabilderna, de ljusbärande änglarna på baldakinen över högaltaret, och utformningen av såväl den stora höjoch sänkbara nunnekronan som det stora brödrakorset, båda försedda med många lampor. ${ }^{768}$ Den birgittinska ikonografin tog då en stor plats.

Frågan om det var olika motiv som betonades för klosterfolk respektive lekfolk i en och samma kyrka kan besvaras jakande. De specifikt birgittinska bilderna riktar sig främst utåt, till lekfolket, medan det marianska dominerar i klostrets inre domäner. De marianska referenserna förekom i alla format och medier samtidigt. De har till och med placerats på de centimeterbreda vävda bandens gyllene $\mathrm{m}$ och rosor och i handskrifternas $\mathrm{m}$-formade marginaldekorer. För nunnorna var heliga Birgitta själv närvarande främst genom den dagliga läsningen ur hennes texter, men inte så mycket i de interna bilderna som man kanske skulle kunna tro. Bilderna för nunnornas interna bruk kompletteras även av de texter man regelbundet läste ur Uppenbarelserna. Det finns en stor samstämmighet mellan symbol- och bildurvalet

${ }^{768}$ Fritz \& Elfving 2004 s 35, 37. 
i nunnornas kontext i kyrkan och innehållet i den marianskt tematiskt uppbyggda Cantus sororum.

Det "vanliga" kyrkfolket, pilgrimerna, påverkade bildvärlden i klosterkyrkan i begränsad utsträckning, såvitt man inte hörde till den exklusiva skara som grundade en altarstiftelse och/eller hade en gravplats där. Pilgrimernas visuella bidrag till kyrkorummet var främst de votivgåvor som de förde med sig till de olika altarna som tack för bönhörelsen. När de rörde sig i kyrkorummet kunde de dock ta del av en ovanligt rik bildvärld. Det var dels en bildpropaganda som basunerade ut vilka som var kapellens och altarstiftelsernas patronus, dels ett stort sällskap av helgon som uppmanade kyrkobesökarna till efterföljelse, tröstade dem i nöden och som de kunde förlita sig på när det gällde förböner i livet och inför det hinsides livet. De kunde välja mellan de olika aktörer som förknippades med de olika helgonaltarna, men med största sannolikhet var det jungfru Maria och den heliga Birgitta som stod i centrum för kyrkobesöket. De bevarade avlatsbreven tyder på det. Där nämns framförallt den heliga jungfruns altare, men även Birgittas. Det var kanske i första hand heliga Birgitta som lockade lekfolket till just Vadstena och manade dem att leva i efterföljelse i Uppenbarelserna. Klosterfolket hade redan gjort sitt stora val genom att välja klosterlivet. För dem var det jungfru Maria som var den viktigaste gestalten, medan Birgitta var den som lett dem dit och som gav dem riktning och stöd på den vägen.

Vi återvänder avslutningsvis till det i kapitel 1 nämnda röda baner som ledde nunnorna som invigdes i Vadstena kloster den 6 juni 1499. Baneret pryddes av den till motivet viktigaste bilden i klostret, påbjuden av heliga Birgitta. Det bar en bild av Kristus på den ena sidan och av jungfru Maria, på den andra. De inträdande nunnorna skulle följa Kristus på samma oförvitliga sätt som jungfru Maria hade följt sin son och som hon uppmanat heliga Birgitta att göra. Den heliga Birgitta själv ingick inte i detta bildkoncept. Hon kan däremot sägas vara den som ledde nunnorna fram till sitt inträdesbeslut, och hennes ord skulle ledsaga nunnorna dagligen under resten av deras liv. I nunnornas bildvärld i klosterkyrkan spelade emellertid jungfru Maria, ackompanjerad av den specialgjorda marianska liturgin (Cantus sororum), en större roll än heliga Birgitta. Bilder av klostergrunderskan står här tillbaka till förmån för de rika framställningarna av jungfru Maria och den allt genomsyrande marianska symboliken.

Kyrkorummets scenografi innebär att heliga Birgitta på ett övergripande plan skapade en visuell kontext med en kvinnlig och en manlig pol, där jungfru Maria dominerar i öst och Kristus och apostlarna dominerar i väst. Men på ett mer detaljerat plan innebär den samtidigt att Maria och Kristus är framställda omväxlande oavsett vilket håll man tittar åt. Jungfru Marias roll är mycket framträdande, framförallt ur nunnornas perspektiv. Att klostret var en skapelse främst för kvinnor märks också i det sammantagna bildprogram som man kan utläsa ur kyrkorummets gestaltning. Läser man rummet och dess bilder i turordning från öster till väster så kommer först jungfru Maria, sedan heliga Birgitta, följd av nunnorna. Därefter kommer apostlarna och sist bröderna. Att denna klosterskapelse var till för nunnorna, och att bröderna skulle betjäna dem, framgår således av hur kyrkorummets 
bildskrud är organiserad, från öst till väst. Hela klosterkyrkans kyrkorum kan därför sägas skapa en symbolisk framställning av Birgittas budskap: följ mig så som jag följer Maria och som Maria följde Jesus! Vadstenapilgrimen som står nedanför högkoret befinner sig då i gott sällskap med jungfru Maria och heliga Birgitta som går före, hon står med Katarina och Petrus Olofsson vid sin sida och med apostlarna som stöd i bakgrunden. Pilgrimen ingår då i gemenskapen tillsammans med alla kyrkobesökarna, liksom de i golvet gravlagda och de många helgonen vid de olika altarna. Den allmänkyrkliga sfär av helgon som pilgrimen rör sig i inom lekmannadelen, omsluts helt av heliga Birgittas skapelse och ger rummet dess speciella karaktär. Man kan säga att heliga Birgitta byggde vidare på tanken att kyrkan som organisation också är en symbol för jungfru Maria och varje enskild kyrkobyggnad ett förkroppsligande av detta. Utifrån detta lade hon, genom den originella strukturen i interiören en grund, och genom efterföljarnas försorg förstärktes den i sin birgittinska särart genom de birgittinska tilläggen (fr.a. skrinet, Birgittaaltaret, men även Katarinaaltaret och Petrus Olofssons grav) och anpassades till att följa normal katolsk praxis. Därigenom förenades det specifikt birgittinska och det allmänkatolska, på samma sätt som heliga Birgitta själv fogades in i redan kända motiv, som exempelvis Jesu födelse. Detta menar jag är ett mycket medvetet bildbruk, där förutsättningarna som skapades av heliga Birgitta, på ett målinriktat sätt vidareutvecklades av hennes efterföljare i Vår heligaste frälsares orden i Vadstena. 